\title{
DIE BEGRIP PASTORAAT BY FABER EN VAN DER SCHOOT KRITIES BESKOU
}

\author{
DR. M. J. DU P. BEUKES
}

\section{INLEIDING}

(a) Motivering van die ondersoek:

Gedurende die laaste aantal jare het daar wye belangstelling ontstaan vir die vak Pastorale Psigologie. Die sigbare bewys vir hierdie stelling is die feit van die enorme hoeveelheid werke wat op hierdie gebied gepubliseer is. Hierdie oorvalling van pastoraal-psigologiese werke het die vraag na vore gebring of hierdie vak werklik tot die Praktiese Teologie behoort. Die oorbeklemtoning van die Psigologie het aanleiding gegee tot:

(i) Die opvatting dat Psigologie ' $n$ wesenlike deel van die Poimeniek is.

(ii) Dat baie pastors ' $n$ groter belangstelling vir die Psigologie as vir die Poimeniek ontwikkel het.

(iii) Die beoefenaars van die Poimeniek het onseker geword oor die plek, objek en betekenis van die Poimeniek binne die raamwerk van die teologiese ensiklopedie. ${ }^{1}$ )

Om bogenoemde stellings te fundeer, het die werke van Faber en Van der Schoot ' $n$ groot rugsteun geword, en is kritiese besinning op hulle werke noodsaaklik.

(b) Seleksie:

Vanweë die groot hoeveelheid werke wat deur bogenoemde skrywers gepubliseer is, moes noodwendig 'n seleksie gemaak word met die oog op hierdie studie. Die werke wat geraadpleeg is, is slegs dié waarna in die voetnotas verwys word. Die aspekte wat bespreek word, is ook slegs ' $n$ kort weergawe van die skrywers se opvattings.

(c) Werkwyse:

Met die kritiese beoordeling van 'n bepaalde skrywer se werk is ' $n$ dubbele werkswyse moontlik, $n l$. 'n lengtedeursnit of dwarsdeursnitbeskrywing. ${ }^{2}$ ) Met die oog op voorkoming van

1) H. D. A. du Toit, Praktiese Toologie Vandag, Lesing gehou tydens die stigtingsvergadering van die Praktiese Teologie werksgemeenskap van Suid-Afrika 1968, bls. 1.

2) S. P. J. J. van Rensburg. Nuwe Testament Teologie, Diktaatlesings 1964. 
herhaling is laasgenoemde wyse gevolg. Dit beteken dat nie eers ' $n$ totale beskrywing van die betrokke skrywers se gedagtegang gegee word en dan ' $n$ kritiese beoordeling nie, maar dat die skrywers se opvattings weergegee word en direk daarna die kritiese besinning.

Die teologiese fundering in paragraaf 2 is slegs ' $n$ kort prinsipiële besinning en bedoel nie om ' $n$ volledige beskrywing van die Pastoraat te wees nie.

\section{FABER EN VAN DER SCHOOT SE PRAKTIES-TEOLOGIESE OPVATTING}

\section{Verskillende Denkrigtings:}

Uitgaande van die Praktiese Teologie se objek, sy verhouding tot ander teologiese vakke en sy gebruikmaking van hulpwetenskappe, kan die Praktiese Teologie in verskillende Denkrigtings ingedeel word. ${ }^{1}$ Prof. dr. J. I. de Wet deel die verskillende Denkrigtings in drie groepe in, naamlik Die Praktiese, die spekulatiewe en die prakties - Teologiese Denkrigting. ${ }^{2}$ ) Prof. dr. H. D. A. du Toit noem die verskillende denkrigtings anders, naamlik die Histories-teoretiese skool en die Empiries-Psikologiese skool. ${ }^{3}$ )

\section{(i) Die Praktiese Denkrigting: -}

Hierdie rigting word verteenwoordig deur die meeste Praktiese Teologie beoefenaars wat die vakgebied van die Praktiese Teologie aandui met die naam diakonale of amptelike vakke. " ) „By hierdie opvatting en die variante daarvan gaan dit in die laaste instansie in die Praktiese Teologie om die vorm en metode van die kerklike verkondiging. ${ }^{5}$ ) Die hoofsaak is hier die vaardigheid waarmee die ampswerk verrig word, en die sigbare resultate wat verkry word.

Die bestudering van die Praktiese Teologie word hier gesien as die effektiewe daarstelling van 'n goeie ampspraktyk. Die vorm en die metode van die verkondiging staan hier primêr en nie die prinsipieel - teologiese nie. Die vraag wat hier voorop staan, is nie wat sê die Bybel t.o.v. die verkondiging nie, maar hoedanige verkondiging skyn die effektiefste te wees. Dit gaan dus hier om ampstegnieke en om niks anders nie.

Die veronderstelling dat dit in die Praktiese Teologie om ampstegnieke gaan, het noodwendig tot gevolg dat die Praktiese Teologie uitgelewer word aan sy hulpwetenskappe. So word die

1) J. I. de Wet, Die Gehalte en Gestalte van die Praktiese Teologie sedert die begin van die Twlntigste Eeu, Hervormde Teologiese studies, Jaargang 22 aflewering 4 , bls. 197.

2) J. I. de Wet, a.w., bls. 198.

3) H. D. A. du Toit, a.w., bls. 4. Met hierdie twee Denkrigtings wil hy nie alle Praktiese Teologie rigtings aandui nie, maar slegs twee rigtings wat afwyk van die korrekte beskouing.

4) Verteenwoordigers van hierdie benaming en al sy konsekwensies is onder andere die Gereformeerdes A. Kuyper, K. Dyk, T. Hoekstra en andere.

5) J. 1 . de Wet, a.w., bladsy 198. 
homiletiek uitgelewer aan die retoriek, die kategetiek aan die didaktiek, en die poimeniek aan die psigologie. Hier word sonder meer aanvaar dat die pastoraat en 'n psigo-analitiese proses dieselfde is.

Deur hierdie denkrigting word 'n kerklike praktyk opgebou sonder enige teologiese principia. Die feit dat dit hier gaan om die vorm en metode van die verkondiging alleen, lei daartoe dat alle ander teologiese wetenskappe as oorbodig vir die Praktiese Teologie beskou word. Die Praktiese Teologie word langs hierdie weg uit die teologiese Ensiklopedie uitgelig en gewerp in die skoot van hulpwetenskappe. So gesien is die Poimeniek nie meer 'n teologiese wetenskap nie maar 'n ,psychologische Beratung mit religiösem Einshlag".6)

Dat hierdie die rigting is wat Faber en Van der Schoot wil bewandel, spreek duidelik uit hulle werke. Nêrens in hulle boeke bepleit hulle ' $n$ beter teologiese toerusting met die oog op die pastoraat nie, maar telkens weerklink die refrein, en word die klem gelê op die praktiese werksaamheid van die pastor. Die nood van die Praktiese Teologie word gesien as geleë in die feit dat die klem te veel gelê word op die teorie van die Praktiese Teologie en nie op die werklike praktiese toepassing nie. „Nu de Universiteiten hoe langer hoe verder van de maatschappij komen te staan en ook de hoogleraren hun levend contact met de realiteit van het pastoraat verliezen, gaan zij steeds meer over de theorie van de praktische theologie spreken in plaats van de studenten op de praktische aspecten van hun aanstaande beroep voor te bereiden." ${ }^{\prime 7}$ ) Van der Schoot pleit ook dat die klem in die toekoms meer op die .,pastor practicus"' is nodig dat die aanstaande pastors 'n spesifieke "training" sal ontvang. ${ }^{9}$ ) Voortdurende aanraking met die praktyk is noodsaaklik. Die studente moet pastorale gesprekke voer, verslag kom gee, en gesamentlik die regte benaderingswyse vanuit die praktyk vind. ${ }^{10}$ ) Net soos die praktiese werk van die mediese student onontbeerlik is, is die "clinical training" onontbeerlik vir die pastor. ${ }^{11}$ ) By so 'n "clinical training" sal die inhoud van die onderrig nie teologiese probleme wees wat tydens die gesprek na vore gekom het nie, ook

6) E. Thurneysen, Die Lehre von der Seelsorge. Zweite Auflage, Zurich 1957, bls. 186.

7) H. Faber, Praktische Theologie?, Ministerium, tijdschrift voor praktiesche theologie en ambtelijke praktijk, 1e jaargang - no. 10 - November 1967, bls. 162.

8) H. Faber en E. van der Schoot, Het Pastorale Gesprek. Een PastoraalPsychologische studie, 1962, bls. 244.

9) H. Faber, Analyse van een gespreksverslag, Ministerium, 3e jaargang no. 3, Maart 1969, a.w., bls. 50 .

10) Volgens H. Faber, Pastoral Care and Chinical Training in America, Arnhem, 1961 , is met die "clinical training" in Amerika "n goeie grondslag gelê vir alle toekomstige Pastorale opleiding.

11) H. Faber, Praktische Theologie?. Ministerium, 1e jaargang no. 10November 1967, bls. 162. 
nie die vraag in hoeverre die Woord verkondig is al dan nie, maar die vraag of die gesprekstegniek, die persoonlike benadering, op die regte wyse geskied het. ${ }^{12}$ ) Nie die inhoud van die woord wat gespreek is, is hier die oorheersende nie, maar die juiste ",habitus" van hom wat die woord gespreek het: „Het komt dus niet zozeer aan op de woorden, die wij gebruiken - zij zijn natuurlik niet onbelangrijk! - maar op het feit, of wij onsop de juiste manier voelen ten opzichte van de ander met zijn problemen en of wij van daaruit als vanzelf de juiste woorden vinden. Wij moeten, zoals men tegenwoordig vaak zegt, in de juiste relatie staan, door de goede grondgevoelens ten opzichte van de ander geleid worden. Wij moeten de ander in de echte zin van het woord willen bijstaan, op onze manier een pastor voor hem willen zijn. ${ }^{13}$ ) In sy onderrig moet die leidende persoon van die gespreks-,,training", praktiese adviese gee hoe om al die hindernisse tot 'n juiste „habitus" teenoor die pastorale objek te oorbrug. Hierdie praktiese adviese word hoofsaaklik verkry uit psigologiese gegewens en nie uit teologiese principia nie. ${ }^{14}$ )

Besonder betekenisvol is die feit dat Faber en Van der Schoot met hulle ganse metode wil beklemtoon dat die Praktiese Teologie nie slegs met die prinsipiële, die aard en die doel van die verkondiging te doen het nie, maar ook met die vorm en die metode. ${ }^{15}$ ) Die formeel - metodiese aspek van die verkondiging word nie links gelaat nie. „Het is niet alleen de vraag, wát men de mensen moet zeggen, maar op z'n minst even zeer hoé men dat moet doen." ${ }^{16}$ )

Hulle bly egter in gebreke om die „hoe” te bou op 'n teologiese grondslag. Die vorm en metode lei hulle hoofsaaklik af van nie-teologiese hulpwetenskappe. Die hulpwetenskappe is wel van belang vir die Praktiese Teologie, maar is nie die oorheersende nie. As die Poimeniek teologiese wetenskap wil wees en bly, sal die uitgangspunt nie die Psigologie kan wees soos by Faber en Van der Schoot nie, maar die Skrif, nie alleen wat die formele betref nie maar ook die materiële. Dit sal gevrywaar moet word van die tendens om sigself uit te lewer aan nie-teologiese wetenskappe. Soos elke teologiese wetenskap, sal dit slegs een objek moet hê, nl. die openbaring van God in Jesus Christus. ${ }^{17}$ ) Met die vorm en metode van die verkondiging moet erns mee gemaak word, maar hierdie vorm en metode moet in die eerste plek verkry word uit die Skrif, uit teologiese principia. In die Skrif self sien ons dat 'n bepaalde verkondigingsgestalte ' $n$ bepaalde vorm aangeneem het, en is dit nie waar dat die Skrif ons niks van die vorm en metode van die verkondiging leer nie. ${ }^{18}$ )

12) H. Faber en E. van der Schoot, Het Pastorale Gesprek, bls. 238.

13) H. Faber en E. van der Schoot, Het Pastorale Gesprek, bls. 22.

14) Vergelyk die besondere klem wat Carl R. Rogers ('n psigoloog) se .counseling" metodes in hulle werke inneem, Het Pastorale Gesprek, Hoofstuk iii.

15) Vergelyk J. I. de Wet, a.w., bls. 200. 
Omdat die Poimeniek teologiese wetenskap is, kan die Psigologie slegs dien as hulpwetenskap. ${ }^{19}$ ) Praktiese beoefening van die vak is seker noodsaaklik, die belangrikste sal egter die inhoud van die gesprek moet wees, en nie die juiste houding en spreekwyse nie. Die Heilige Gees maak per slot van sake nie gebruik van 'n juiste "habitus" om die geloof te wek en te versterk nie, maar die Woord wat getuig van die drie-enige God se verlossende handelinge in Jesus Christus. ${ }^{20}$ )

\section{(ii) Die Empiries — Psigologiese skool: -}

Hierdie is 'n Prakties Teologiese denkrigting waar die uitgangspunt die empiriese gegewene is, en dan in die besonder die psigolngiese gesteldheid van die empiriese gegewene wat voorhande is. ${ }^{21}$ ) Die bepalende vir die verkondiging hier is die mens tot wie die verkondiging gerig is. Die vraag wat vooropstaan, is nie die vraag na die regte verkondiging van die Woord nie, maar die vraag na die psigologiese gesteldheid van die mens tot wie die verkondiging gerig is. Die Woord kan nie sondermeer verkondiging word nie, eers moet vasgestel word hoedanig d'c mens se psigologiese gesteldheid is. Die psigologiese gesteldheid soos teenwoordig in die hier eksisterende mens is die uitgangspunt, die aanknopingspunt vir die verkondiging van die Woord. ${ }^{22}$ ) 'n Moontlikheid in die mens self moet eers gesoek word vir die vatbaarheid van die Woord. Eers dán kan die Woord effektief gespreek word as hierdie moontlikheid ontdek is. Hier word die fundering en die praktiese toepassing van die verkondiging bepaal deur bepaalde psigologiese tendense in die mens. So o.a. is nog onlangs gesê dat die Jeug-pastoraat noodsaaklik is omdat die jeug van vandag mense is wat oopvragend besig is om antwoord te soek oor fundamentele kwessies. ${ }^{23}$ ) Elke empiriese psigologiese gesteldheid nadat dit ontdek is, vra ' $n$ boodskap wat juis sal pas by hierdie pas ontdekte. Elke ouderdomsgroep, milieu-fase en psigologiese gesteldheid hetsy innerlik of uiterlik veroorsaak, vra 'n ander boodskap. ${ }^{24}$ )

16) H. Faber en E. van der Schoot, Het Pastorale Gesprek, bls. 199.

17) H. D. A. du Toit, a.w., bls. 7.

18) Vergelyk bv. die verskil in vorm tussen Paulus se sendingsprediking en sy binnegemeentelike prediking.

19) Sien E. Thurneysen, a.w.. hoofstuk $X$.

20) Vergelyk Joh. 16:14 en Rom. 10:17.

21) Verteenwoordigend van hierdie rigting is veral F. Niebergall, Praktische Theologie. Tubinqen, 1918.

22) Is dit nie dieselfde opvatting as predikante wat sê die gemeente moet eers geken word alvorens pastoraat moontlik is nie?

23) W. J. de Klerk. Die Pastoraal - Psigologiese benadering van die Jeug, Lesing gehou tydens die stigtings vergadering van die Praktiese Teologie werksgemeenskap van Suid-Afrika, 1968, bls. 1.

2) P. J. Roscam Abbing ontdek niks minder nie as 92 verskillendes tipes wat in verskillende boodskap vra, Zielszorg ten dienst van allen die Zorg voor hun naaste hebben, $S^{\prime}$ Gravenhage, 1962. 
Bogenoemde is die beeld wat verkry word by Faber en Van der Schoot. Dit bring ingrypende konsekwensie vir die Praktiese Teologie mee. Dit verlaag die Praktiese Teologie tot 'n suiwer antoropoliges-psigologiese wetenskap. Hier is dit nie meer die Skrif wat oproep tot verkondiging, die transendente Woord wat die mens aanspreek, oproep en in beweging bring nie, maar die mens soos hy voorhande eksisteer. Die uitgangspunt vir die verkondiging lê hier nie opgesluit in die Skrif self nie, maar in die mens. Dit is hier nie meer die een verlossende Woord Jesus Christus wat tot spreke gebring moet word nie, maar 'n verskeidenheid van woorde ooreenkomstig die mens se aard, sy lewensopvattinge, ens.

\section{WAT IS PASTORAAT?}

\section{A. Materieel}

Faber omskryf die pastoraat „,als helpen van de mens om de juiste verhouding tot God te vinden" of ,als het de ander laten zien, dat hij in het licht van God staat en wel op zulk een manier, dat hij dit innerlijk aanvaardt". ${ }^{1}$ )

Met drie Bybeltekste fundeer Faber sy definisies. Ten eerste die woorde van Markus waarmee hy Jesus Christus se prediking opsom: „Die tyd is vervul en die koninkryk van God het naby gekom; bekeer julle en glo die evangelie." ${ }^{2}$ ) Ten tweede die woorde wat Jeremia in die tempelpoort moet gaan uitroep: „Staan in die poort van die huis van die Here, en roep hierdie woorde daar uit en sê: ,Hoor die woord van die Here, o hele Juda, wat deur hierdie poort ingaan om die Here te aanbid! So sê die Here van die leërskare, die God van Israel: Maak julle weë en julle handelinge goed, dat Ek julle kan laat woon in hierdie plek." 3 ) Ten derde die vertroosting uit Jesaja: „Troos, troos my volk, sê julle God. Spreek na die hart van Jerusalem, en roep haar toe dat haar stryd verby is, dat haar skuld betaal is, dat sy uit die hand van die Here dubbel ontvang het vir al haar sondes." 4 )

Uit bogenoemde tekste konkludeer hy dat Pastoraat oproep is tot bekering, vermaning en die belofte van troos en vergewing. Deur die oproep tot bekering, vermaning en woord van troos moet die regte relasie tot God geskep word. Die belangrikste vir hom is nie die inhoud van die vermanende, troostende en oproepende woord nie, maar die houding van die pastor wat daaruit afgelei word, ,het bij de ander zijn". ${ }^{5}$ ) Hieruit blyk dat die belangrikste vir hom nie

\footnotetext{
1) H. Faber en E. van der Schoot, Het Pastorale Gesprek, bls. 27.

2) Markus 1:15.

3) Jeremia $7: 2$ en 3.

4) Jesaja 40:1 en 2 .

5) Faber en van der Schoot, Het Pastorale Gesprek, bls. 37.
} 
die totstandkoming van 'n bepaalde relasie tussen die mens en God is nie, maar tussen die betrokkene en die pastor.

Eers vanuit hierdie relasie, die vertrouensverhouding, die geopenheid vir mekaar, kan ware pastoraat beoefen word.

Van der Schoot wil ook 'n definisie van die pastoraat gee en stel: „Zielszorg is het leggen en onderhouden van een tussen menselijke relatie, waarin de zielszorger de ander op een bepaald ogenblik of in een bepaalde fase van zijn leven ontmoet en begeleidt om hem te helpen het Woord Gods in zijn situasie te verstaan." Die laaste deel van die definisie omskryf hy ook soos volg: „om hem te helpen zijn leven als gave en opdracht van God te verstaan en te beleven." ${ }^{.6}$ ) Dit gaan hier om die verstaan van Gods Woord in die konkrete situasie waarin die mens sig bevind. Die mens word met die Woord aangespreek midde in sy alledaagse lewe, word opgeroep om die Woord gestalte in sy lewe te laat aanneem. Voordat hierdie Woord egter gespreek kan word, is dit eers nodig dat die „tussenmenslike relasie" geskep sal word. Eers moet 'n situasie geskep word waarin pastor en objek van die pastoraat mekaar gevind het. Net soos by Faber is hier die grootste en die belangrikste nie die inhoud van die Woord nie, maar die proses van 'n goeie relasie-totstandkoming. Eers dán is daar werklik sprake van sukses in die pastorale gesprek as die ander een voel dat hy onvoorwaardelik deur die pastor aanvaar is: „Ik hoop, dat voorgaande uiteenzetting heeft duidelijk gemaakt, waarom ik in de omscrijving van een moderne vorm van zielszorg zo sterke nadruk leg op: ,het leggen en onderhouden van een tussenmenslijke relatie! Op veel dringender wijze en ook heel anders dan voorheen is dit een onmisbare psichologische voorwaarde voor het al dan niet slagen van het pastorale gesprek. ${ }^{\prime 7}$ )

Opvallend is die feit dat die psigoterapeut A. Poslavsky feitlik dieselfde definisie gee van sy vakgebied: „Psychoterapie is het leggen van een tussenmenslijke relatie, waaraan en waardoor de verwerklijking van tot dusverre ongerealiseerde potentialiteiten mogelijk is, relatie, die voor de patiënt onvergelijkbaar genoemd mag worden." ${ }^{\prime \prime}$ ) Dit is die tot standbringing van hierdie relasie wat die uiteindelike vrugte op die pastorale gesprek voortbring en nie meer die Heilige Gees deur die Woord nie.

6) E. van der Schoot, Hoofdstukken uit de Pastorale Psychologie, Utrecht, 1959, bls. 31 .

i) E. van der Schoot, Hoofdstukken uit de Pastorale Psychologie, bls. 33.

8) A. Poslavsky soos aangehaal deur E. van der Schoot, Hoofdstukken uit de Pastorale Psychologie, bls. 31. 


\section{B. Formeel}

Pastoraat kan omskryf word: „als verkondiging van het Woord Gods aan de enkeling. ${ }^{\prime \prime}$ ) Smelik stel: „Het pastorale gesprek is een der vormen, niet meer en niet minder, waarin Christus Zijn gesprek met de wereld voortzet tot aan het einde der tijden."10)

Bogenoemde beoefenaars sien die pastoraat as 'n gestalte van die verkondiging. Die Woord moet gebring word tot die mens in sy konkrete situasie. By hulle is daar geen voorspel of naspel, geen skoonmaking van die terrein, geen moontlikheid van aanknoping soek alvorens die Woord gebring word nie: „Seelsorge ist und bleibt Wortverkündigung an den Einzelnen und kann und will nie etwas Anderes sein."'11) Die Woord word direk aan die mens verkondig.

Die formele uitwerking van die pastorale gesprek soos ons dit aantref by Asmussen, Smelik en Thurneysen word deur Faber en Van der Schoot afgewys as te „,directive“. ${ }^{12}$ ) Die Woord moet nie direk verkondig word nie. Daar moet eers die regte gevoelsrelasie, ${ }^{13}$ ) gevoelsmatige kontak ${ }^{14}$ ) en wedersydse begrip ${ }^{15}$ ) geskep word. As die Woord direk gespreek word kom bogenoemde nie tot stand nie en is daar geen sukses met die pastorale gesprek nie.

Die vraag is nou hoe kom hierdie juiste relasie tot stand? Volgens Faber is dit hier waar die raaklyn van Teologie en Psigologie mekaar sny. Hier word die Psigologie 'n onvoorwaardelike voorvereiste vir die regte beoefening van die Teologie. Hier word dit duidelik dat die teologiese principia alleen ware gestalte in die lewe van die mens kan vind as die Psigologie as medebondgenoot in die stryd ingetrek word, as die teologie vir sig die ruimte en plek laat skep deur die Psigologie. Onvoorwaardelike voorvereiste vir die pastoraat word hier die visies van twee Psigoloë, naamlik Fosdick en C. R. Rogers. Hierdie direkte oorskakeling van Teologie na Psigologie is geen struikelblok nie omdat dit vir Faber en Van der Schoot in beide gaan om dieselfde. ${ }^{18}$ )

Uit die Psigologie van Rogers wil Faber veral twee begrippe direk by die Pastoraat betrek, naamlik

(a) „empathie"::17)

17) Faber en van der Schoot, Het Pastora:e Gesprek, bls. 32.

9) H. Asmussen soos aangehaal deur E. van der Schoot, Hoofdstukken uit de Pastorale Psychologie, bls. 30.

10) E. L. Smelik soos aangehaal deur E. van der Schoot, Het Pastorale Gesprek, bls. 131.

11) E. Thurneysen, a.w., bls. 175.

12) Sien E. van der Schoot, Hoofdstukken uit de Pastorale Psychologie, bis. 33, en Faber en van der Schoot, Het Pastorale Gesprek, Hoofstukke i, ii en iv.

13) Faber en van der Schoot, Het Pastor'e Gesprek, a.w., bls. 10.

14) Faber en van der Schoot, Het Pastorale Gesprek, a.w., bis. 14.

15) Faber en van der Schoot, Het Pastora!e Gesprek, a.w., bis. 15.

16) Vergelyk noot ${ }^{7}$ ). 
Dié begrip wil sê die pastor moet hom in die gevoelens van die objek van die Pastoraat inleef. Die persoon tot wie die pastoraat gerig is moet voel dat die pastor met hom meeleef.

(b) „Non directive method":

Dit is om die objek van die pastoraat nie direk aan te spreek nie, maar op so ' $n$ wyse die persoon se eie woorde terug te spieël, dat die persoen gaandeweg sy hart uitpraat. ${ }^{18}$ ) Deur hierdie proses besef die ander persoon dat die pastor werklik besig is om hom te help om tot klaarheid en duidelikheid oor homself te kom. ${ }^{19}$ )

Die volgende ooreenkomste tussen pastoraat en Psigologie hou Faber ons voor

(i) In beide moet die pastor en die terapeut nie .,directive" wees nie, eers langs die weg van „,counseling" moet die juiste relasie geskep word. „Een pastoraal gesprek is als het willen landen op ein eiland; je moet eerst om het gehele eilund heen gevaren zijn, voordat, je zeker weet dat je de goede landingsplaat gevonden hebt". ${ }^{20}$ )

(ii) Die wyse van optrede van beide pastor en terapeut is bepalend vir die uiteindelike sukses. „De innerlijke bevijnding, die de boodschap teweegbrengt, de aanvaarding, dat men in het licht van God staat, vinden hun grond niet allen in de woorden, maar ook in het feit, dat dé woorden in een zeer bepaalde relatie, een relatie, die door liefde gekenmerkt wordt, gesproken worden." ${ }^{21}$ )

(c) Beoordeling:

Om die standpunt van Faber en Van der Schoot te beoordeel, sal dit nodig wees dat ons in die eerste plek die vraag moet vra wat sê die Skrif. Dit gaan in hierdie ondersoek dus nie om die vraag na wat ons oor die Pastoraat sê en dink nie. Dit gaan enkel oor die vraag na wat die Bybel, of liewer God in sy Woord, oor die Pastoraat sê. ${ }^{22}$ )

(a) MATERIEEL

(i) Die Herder-Beeldspraak in die Skrif:

(a) Die Ou Testament:

In die Ou Testament betuig God homself as die groot Pastor wat seën met hemelse en aardse seëninge, die

18) Faber en van der Schoot, Het Pastorale Gesprek, bls. 31.

19) Faber en van der Schoot, Het Pastorale Gesprek, bls. 36.

20) Fosdick soos instemmend aangehaal deur Faber in, Het Pastorale Gosprek, bls. 21.

21) Faber en van der Schoot, Het Pastorale Gesprek, a.w., bls. 37

22) J. I. de Wet, Poimeniek. Diktaatlesings, 1967, bis. 1. 
Een wat sy volk verlos uit hulle nood en ellende..$^{23}$ ) Hy betuig sy Herderskap aan die kudde deurdat Hyself aardse herders oor die volk aanstel. ${ }^{24}$ ) Die taak van hierdie herders is om die volk so op te pas dat hulle in die verordeninge van die Here sal wandel, en sy insettinge sal onderhou. ${ }^{25}$ )

(b) Die Nuwe Testament:

Dieselfde bewoënheid van God as Herder oor sy volk tref ons ook aan in die Nuwe Testament. In die Nuwe Testament, kan ons sê, word hierdie bewoënheid van God sigbaar in die vleeswording van Jesus Christus. „Die Herderskap van God vind juis sy volledigste uitdrukking in die verlossing wat God in en deur Jesus Christus vir sy volk bewerk". ${ }^{26}$ ) Omdat $\mathrm{Hy}$ die Een is wat die werk van die Vader op die aarde kom doen, word Hy die Herder by uitnemendheid genoem, die Goeie Herder, ${ }^{27}$ ) die Groot Herder. ${ }^{28}$ ) Sy pastoraat het die ryk van God tot inhoud: „Dat Rijk predikt Hij. Dat Rijk brengt $\mathrm{Hij}$. Hij verkondigt en dragt het. Hy maakt de krachten van het Rijk voelbaar. Hij richet tekenen van het Rijk Op. Hij zet mensen in de lichtkring van het Rijk. ${ }^{29}$ )

Om die uitvoering van God se Herderskap onder sy kudde voort te sit, stel Jesus Christus self herders aan. ${ }^{30}$ ) Die taak van hierdie herders is „om die heiliges toe te rus vir hulle dienswerk, tot opbouing van die liggaam van Christus totdat ons almal kom tot die eenheid van die geloof en van die kennis van die Seun van God, tot 'n volwasse man, tot die mate van die volle grootte van Christus." ${ }^{11}$ ) Dit gaan dus om "die volheid en eenheid van die geloof" in Jesus Christus. Die herders moet weiding verskaf en hierdie weiding is niks anders as die verkondiging van die goddelike Woord nie. ${ }^{32}$ )

23) Genesis 49:24, Psalm 23 en Psalm 28:9.

24) In Numeri 27:17 word die leiers van die volk Israel geteken as herders.

25) Ezegiël 37:24.

26) J. I. de Wet, Ditktaatlesings, bls. 4.

2i) Johannes 10:11.

28) Hebreërs 13:20.

29) M. H. Bolkenstein, Zielszorg in het Nieuwe Testament, Den Haag, 1964, bls. 33.

30) Johannes 21:15 en Efesieërs 4:11.

31) Efesiërs 4:11 en 12.

32) Formulier om die Dienaars van die Goddelike Woord te bevestig. Kerkboek, bls. 161. 
(ii) Die Bybelse Nasorg:

Uit bg. het dit seker al duidelik geword dat die pastoraat hoofsaaklik gerig is tot mense wat reeds gelowiges geword het. Nie alleen is dit nodig dat die mens tot die geloof in Jesus Christus sal kom nie, die mens moet ook in hierdie geloof bewaar en versterk word. Die geloof moet opgebou word. Aangegryp deur hierdie waarheid, het die apostel Paulus dit nodig geag om telkens weer terug te gaan na hulle aan wie hy eenmaal die Woord verkondig het. $\mathrm{Na}$ so 'n opvolgbesoek aan die gemeentes wat gestig is op sy eerste sendingreis word vertel: „En die gemeentes is versterk in die geloof en het elke dag vermeerder in getal. ${ }^{.33}$ ) Hierdie nasorgwerk van die apostel Paulus moes verkondiging van die goddelike Woord gewees het, want versterking in die geloof en vermeerdering in getalle geskied nie anders as deur die verkondiging van die Woord nie.

Ook die briewe wat die apostel Paulus skryf aan gemeentes wat reeds tot die geloof gekom het, dra hierdie nasorgkarakter. Inhoudelik is die briewe getuienis van Jesus Christus se persoon, woord en werk, 'n oproep tot die geloof in Jesus Christus en ' $n$ vermaning tot onderhouding van God se gebooie uit dankbaarheid vir die geskonke heil in Jesus Christus.

Opvallend is die feit dat ook die Evangelie van Lukas geskryf is om te dien as onderrigtende nasorgwerk. Teofilus het reeds die evangelie gehpor; maar daar bestaan nog twyfel by hom „,sodat $u$ met volle sekerheid kan weet die dinge waaromtrent $u$ onderrig is." ${ }^{34}$ ) Lukas wil nou met sy evangelie niks anders doen nie as onderrigtende nasorg, sodat Teofilus ,met volle sekerheid kan weet. ${ }^{35}$ ) Vir die pastoraat as nasorg het die gedeelte Lukas 1:1-4 groot betekenis: -

(1) Die Evangelie dien as onderrigtende nasorg, want Lukas wil vir Teofilus tot "volle sekerheid" bring aangaande Jesus Christus se persoon, woord en werk. Nie net vir Teofilus nie, maar vir alle gelowiges.

(2) Die inhoud van Lukas se onderrigtende nasorg is Jesus Christus en niks anders nie.

(3) Hy wat onderrigtende nasorg bedien, moet ten volle vertroud wees met die inhoud van sy boodskap: „nadat ek van vooraf alles noukeurig ondersoek het. ${ }^{.36}$ )

33) Handelinge 16:5.

34) Lukas 1:4.

35) Lukas 1:4(a).

36) Lukas 1:3(b). 
(4) Hierdie onderrigtende nasorg moet ordelik geskied: „om dit in volgorde aan u te skrywe." ${ }^{37}$ )

(5) Die Woord van God wil voortgang hê in die wêreld daarom moet die een wat reeds die Woord gehoor het, dit weer verkondig aan die volgende. Lukas het die Woord ontvang van die ooggetuies en dienaars van die Woord"'38) en nou laat hy die Woord voorgang hê deur Teofilus en alle ander gelowiges te onderrig sodat hulle op hulle beurt weer die volgende een kan onderrig.

Ons kan konkludeer dat die pastoraat in die teken van die nasorg staan en dat hierdie nasorg onderrigtend van aard is. Die nasorg kom voort uit die feit dat die Woord reeds gehoor is, en is daarop gemik dat die Woord weer gehoor moet word. Die taak van die nasorg is daarin geleë dat die gemeente opgebou moet word, sodat hulle met volle sekerheid kan weet ${ }^{39}$ ) en dat die heil wat ontvang is weer aan ander deurgegee moet word. Dit wil sê die pastoraat se taak is eintlik lerend, wat daartoe lei dat dit weer missionerend word.

Hierdie nasorg wat verrig word, is tegelyk ook voorsorg. Tydens sy nasorgbesoeke gee Paulus die beslissings van die apostelkonvent van Jerusalem oor aan die gemeentes om te onderhou. ${ }^{40}$ ) Langs hierdie weg wil die apostel Paulus voorkom dat verkeerdhede wat die gemeente ten gronde kan rig, sou insluip.

\section{(iii) Die Besoek Aan de Huise:}

In Mattheus 10, Markus 6 en Lukas 10 vind ons die uitsendingsgeskiedenisse. Ons het hier nie te doen met heidensending nie, maar met die voortgaande verkondigingsopdrag van God aan die kinders van die verbondsvolk. ${ }^{41}$ ) Van besondere belang is die inhoud van die boodskap wat die uitgestuurdes moet verkondig: ,Die koninkryk van God het naby julle gekom." ${ }^{.42}$ ) Hierdie proklamasie van die koninkryk van God is verkondiging van die koningsheerskappy van God soos dit sigbaar geword het in Jesus Christus.

In Handelinge 20:20 word direkte getuienis gegee van die verkondiging van die Woord in die huise van gelowiges. Paulus het niks agter gehou van wat nuttig is om dit aan

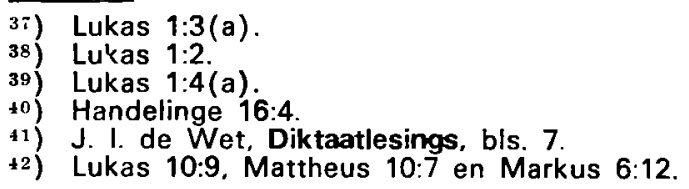


die gelowige Efesiërs te verkondig en hulle te onderrig in die openbaar en in hulle huise nie. Hierdie "wat nuttig is", is verkondiging aangaande Jesus Christus, of soos Paulus dit self stel, die verkondiging van die hele raad van God. ${ }^{43}$ ) Uit al die Bybelse gegewens wat genoem is, kan ons stel dat pastoraat niks anders is as verkondiging van Gods Woord nie, die verklaring en toepassing van die Woord met betrekking tot Jesus Christus se persoon, woord en werk. Die doel van die pastoraat, sien ons aan die anderkant, is die versterking en bewaring in die geloof, die vorming van die lewe in geloof en gehoorsaamheid aan Gods Woord.

Pastoraat is dus in bepaalde gestalte van die kerklike verkondiging wat God self gebruik deur die werking van die Heilige Gees om die mens te bewaar en te versterk in die geloof. Die pastoraat is ' $n$ paraliturgiese gestalte van die verkondiging wat buite die erediens optree, maar nie die erediens vervang nie. Dit is eerder 'n aanvulling van die erediens, wat uit die erediens voorkom en weer daarheen teruglei. ${ }^{44}$ ) Dit kom voort uit die feit dat die Woord gehoor is, en wil daarvoor sorg dat die Woord opnuut gehoor sal word. "Dit is opbou van die gemeente. Dit wil nie privaat vroomheid los van en buite die gemeentelike erediens om opbou nie, maar juis gedurende die week die gemeente so lei dat die gemeente Sondag na Sondag weer en weer in die erediens onder die prediking en by die sakramente sal vergader."45) Dit wil die ganse lewe van die gemeente stel in die lig van God se Woord: „Het huisbezoek moet de gemeente leren om te geloven op Maandag." ${ }^{* 6}$ )

\section{(b) FORMEEL}

Die formele gegewens vir die pastoraat mag nie sondeımeer uit die lug gegryp word of uit die ervaring afgelei word nie. As die pastoraat pretendeer om teologiese wetenskap te wees, wat sig besig hou met die verkondiging aan die huise en enkelinge van die genieente, dan sal die formele ook gebou moet wees op teologiese principia. „'n Kerklike praktyk wat ver en vreemd van die teologiese principia staan, al is dit ook hoe goed in ander gronde gevestig, kan nooit reg wees nie, kan nooit die geloof versterk en die gemeente opbou nie."17)

43) Handelinge 20:27.

44 J. I. de Wet, Diktaatlesings, b/s. 8.

15) J. I. de Wet, Die Werk van die predikant, Hervormde Teologiese Studies, 19de Jaargang Afl. I en II, bls. 21.

16) R. Kaptein, Het Huisbezoek. Agtergrond, problematiek en methode in de veranderde gemeente, Amsterdam, bls. 66.

47) J. I. de Wet, Diktaatlesings, bls. 12 . 
In die Skrif self word nie wetties - casuistiese voorskrifte gegee vir die kerklike verkondiging nie en sodoende ook nie vir die pastoraat nie. Die feit dat nie direkte voorskrifte gegee word nie, is van besondere belang. Dit wil dien as beklemtoning van die feit dat die belangrikste van die verkondiging nie die "hoe" is nie, maar die "wat". Die inhoud en nie die vorm nie. Dit bring noodwendig mee dat in die toerusting vir die pastorale werk die toerusting primêr gerig sal wees op die inhoud van die Woord wat verkondig moet word. Aangesien pastoraat net soos die prediking verklaring en toepassing van die Skrif is, is dit noodsaaklik dat vir die pastorale gesprek die pastor hom net so goed vir Maandagaand se huisbesoek sal voorberei as vir Sondagoggend se preek.

Noodsaaklik vir die pastoraat is dat die mens aangespreek sal word in sy konkrete situasie. Hiervan gee die Skrif ook getuienis. Paulus se rede op die Areopagus ${ }^{+8}$ ) getuig dat hy sy hoorders met hulle Griekse filosofiese agtergrond ken. Sy "homilia" (wat niks anders was nie as verkondiging van Jesus Christus) gerig tot Felix, ${ }^{+\theta}$ ) getuig dat hierdie man hier voor hom nie vreemd aan hom is nie. Opvallend is dat in beide gevalle Paulus voor die aanvang van sy verkondiging nie eers ' $n$ psigo-analitiese proses voltrek nie, maar die Woord direk verkondig. As die Lukas-Evangelie gesien word as 'n voortgaande nasorgwerk aan 'n reeds gelowige, 'n pastorale gesprek in geskrewe vorm, so ook die briewe van Paulus, dan is die pastorale gesprek 'n gesprek wat direkte verkondiging is.

$\mathrm{Na}$ hierdie kort prinsipiële oorsig van die Bybelse gegewens aangaande die pastoraat is dit nou moontlik om oor te gaan tot die beoordeling van Faber en Van der Schoot se beskouings t.o.v. die pastoraat. Hierdie beoordeling wil ons doen aan die hand van 'n paar vrae: -

I. Is daar by Faber en Van der Schoot nog sprake van verkondiging van die Woord in die pastorale gesprek?

As vinnig gekyk word na die onderskeie definisies wat deur hulle gegee word m.b.t. die pastoraat, moet bevestigend geantwoord word. Die beeld verander egter as ons kyk na die formele wyse waarop hulle dit wil doen. Dan skyn dit asof die voorproses waardeur die regte relasie tussen pastor en lidmaat geskep moet word, die verkondiging so verdring dat daar nie veel sprake van verkondiging oor is nie. Faber stel dat Rogers hulle geleer het „dat wij meestal te vroeg zijn met onze verkondiging of vermaning. ${ }^{\prime 50}$ ) Uit

18) Handelinge 17:15-33.

49) Handelinge 24:24-26.

50) Faber en van der Schoot, Het Pastorale Gesprek, bls. 43. 
die gepubliseerde pastorale gesprekke soos in hulle werke verskyn, blyk dat hulle so gehoorsaam aan Rogers was dat dikwels eers na drie of vier gesprekke tot direkte verkondiging oorgegaan word. Tot verkondiging kan eers oorgegaan word nadat die verkondiging eers direk voortgevloei het uit die vooraf gesprek waardeur die regte relasie geskep word. Wat gebeur nou as hierdie regte relasie nie tot stand gekom het gedurende die "counseling" nie? Word die verkondinging dan agterweë gelaat? Faber antwoord self: „Wanneer daar een kans op is, moeten wij het doen. Maar er zijn ook mensen, waarbij men de laaste zorg over hun ziel aan God moet overlaten. ${ }^{51}$ )

In die lig van bogenoemde moet ons stel dat hier nie meer sprake van verkondiging in die volle sin van die woord is nie. Deur die „counseling" metode word die pastoraat verlaag tot ' $n$ psigo-analitiese proses. Die pastoraat is hier nie verkondiging nie maar slegs ' $n$ voorstadium of resultaat van 'n terapeutiese „counseling”. Die grootste en die belangrikste is hier nie die verkondiging van die Woord en sy inhoud nie maar die juiste "habitus". Vorm en metode verdring aard en doel.

II. Is die doel van die Pastoraat by Faber en Van der Schoot nog versterking van die geloof en bewaring in die geloof?

Die vraag na die doel van die pastoraat is deur die eeue heen verskillend beantwoord. Die Roomse kerk sien die doel as die onderwerping, die gehoorsaam wees aan die pous en die Roomse kerk, .,allen moeten gehoorzaam zich onderwerpen aan de moeder de kerk. $\mathrm{Zij}$ is heilsinstelling en heeft macht over de concientien." ${ }^{52}$ ) Vir die Piëtiste is die doel van die pastoraat die versekering van die persoonlike wedergebore syn. ${ }^{53}$ ) Vir die Rasionaliste gaan dit in die pastoraat alleen om die ontplooiing van die rede om uit sigself die waarheid van God te ontdek. ${ }^{54}$ )

Soos reeds aangetoon in die prinsipiële gegewens uit die Skrif, is die doel van die pastoraat nie een van bogenoemde nie, maar versterking van die geloof in Jesus Christus, ' $n$ ordening van die ganse lewe van die mens in geloof en gehoorsaamheid aan die Woord van God.

In hoe verre is hierdie Bybelse visie na te speur in die Pastoraat van Faber en Van der Schoot? In alle eerlikheid kan gesê word dat ons weinig daarvan bemerk het. By

51) Faber en van der Schoot, Het Pastorale Gesprek, bls. 102.

52) P. Biesterveld, Het Huisbezoek, Derde Druk, 1923, bls. 118.

83) P. Biesterveld, a.w., bls. 124.

s4) P. Biesterveld, a.w., bls. 125. 
hulle is daar nie veel sprake van teologie nie maar eerder 'n teorie aangaande 'n terapeutiese proses of tegniek. Dit gaan by hulle nie om die bevryding van die mens uit sy werklike nood, sy sonde nie, maar slegs om die bevryding uit een of ander verstoorde psigiese proses in die betrokkene. Nie om die geloof in die Waarheid van God in Jesus Christus deur die werking van die Heilige Gees nie, maar om die selfontdekking as gevolg van die juiste .habitus" van die pastor wat naas hom kom staan het. Ware pastoraat is „dat men ze helpt zichself te helpen." Deur die „counseling" moet die pastor die betrokkene help om self sy nood te ontdek en eers dan word hy met die Woord van God gekonfronteer. Die mens se selfontdekking word tot voorwaarde vir die ontdekking van God gemaak. Hierdie beskouing het verreikende teologiese konsekwensies: -

(a) Die mens wat nie deur die pastor se „counseling" tot selfontdekking kan kom nie, kan nie glo nie en gaan dus verlore.

(b) Geloof word so gedegradeer tot 'n menslike prestasie wat slegs verkry kan word as daar 'n pastor is wat met hom op die regte wyse kan "counsel".

(c) Hier is dit nie meer die Skrif wat die hoogste norm is nie. Nie die Woord wat die lewe moet vorm na God se wil en welbehae nie, maar die pas gereuliseerde selfontdekking: „Een ander regel is, dat die psichoterapeut geen normen aan de ander voorhoudt, maar hem helpt zijn eigen uit zijn opvoeding meegekregen normen zo zelfstandig mogelijk tot zijn innerlijk verworven bezit te maken. ${ }^{256}$ )

(d) Omdat ,selfontdekking alleen moontlik is as die houding van die pastor korrek is, word die pastor se liefde tot sy medemens verhef tot voorwaarde vir die werk van die Heilige Gees. Alleen as daar ware profetiese barmhartigheid spreek uit die pastor se houding .,kan menselijkerwijs gesproken de Heilige Geest zijn werk doen. ${ }^{67}$ )

Die werk van die Heilige Gees word hier vervang met die "counseling" proses van die pastor, die geloof met die selfontdekking van die lidmaat. Hier word vergeet dat die pastor slegs instrument is, dat God in Jesus Christus met

55) H. Faber en E. van der Schoot, Het Pastorale Gesprek, bls. 87.

56) H. Faber en E. van der Schoot, Het Pastorale Gesprek, a.w., bls. 89.

57) H. Faber en E. van der Schoot, Het Pastorale Gesprek, a.w., bls 98. 
sy Gees eintlik self die Ware Pastor is. Met hierdie beskouing staan ,, de mens te veel in het centrum en niet God en Zijn Woord, terwyl ook het geloof te simplistisch wordt opgevat. ${ }^{-58}$ )

III. Is die beskouing van die ,eers selfontdekking dan die Woord verkondig" Bybels-Reformatories te reverdig?

Basies is hierdie opvatting dieselfde wat ons by predikante aantref wat die gedagte toegedaan is dat 'n predikant eers werklik huisbesoek kan doen as hy die lidmate ken. Vir die evangelieverkondiging word langs hierdie weg 'n voorwaarde geskep. Miskicn kan die vraag gevra word of enige een van die apostels ooit die evangelie sou kon verkondig as dit die voorwaarde was. As dit die voorwaarde is, sal die kerk in die toekoms nog sending in die volle sin van die woord kan doen?

Hierdie opvatting van eers ken of self ontdek berus op 'n verkeerde teologiese opvatting. ${ }^{59}$ ) die opvatting asof daar vir die evangele eers 'n aanknopingspunt gesoek moet word. Die evangelie is nie afh anklik van aanknopingspunte in die mens nie, maar skep self sy aanknopingspunt as dit reg verkondig word. Die apostels kry juis opdrag om doelbewus en doelgerig die evangelie te verkondig sonder om eers aanknopingspunte te soek. ${ }^{60}$ ) Pastoraat is geen „,counseling" waaruit die verkondiging self opgroei nie $\left.^{(i 1}\right)$ maar is verkondiging sondermeer. Daar is nie sprake van dat ons te vroeg met ons verkondiging kan wees nie. Dit gaan net om verkondiging en nie eers om 'n aanloop daartoe nie. Pastoraat is opdrag en darom direkte verkondiging. ${ }^{62}$ )

Hierdie gedagte van 'n aanknopingspunt soek voordat die Woord verkondig word, skep ook die gedagte dat die betrokkenes dink dat die mens só waarklik geken kan word en die regte woord dan gespreek kan word. Faber en Van der Schoot wat hulle „cnunseling" proses direk van die Psigologie oorneem, gee so implisiet te kenne dat ware mensekennis uit daardie bron verkry kan word. Thurneysen het daarop gewys dat kennis van die mens wel by die Psigologie verkry kan word, maar nie ware mensekennis nie. Die enigste bron waar dit waarlik gevind kan word is in die Skrif. Op grond hiervan stel hy: „Das Ansprechen

58) K. Dijk, De Dienst Der Kerk, J. H. Kok, N.K. Kampen, 1952, bls. 163.

59) J. I. de Wet, Diktaatlesings, a.w., Deel bls. 1.

co) Sien Mattheüs 28:19, Markus 16:15, Handelinge 1:8.

61) H. Faber en E. van der Schoot, Het Pastorale Gesprek, bls. 100.

62) R. Kaptein, Het Huisbezoek, bls. 78. 
des Menschen im Seelsorgegesprächsetzt MenschenKenntnis voraus: Die Seelsorge bedarf darum der Psychologie als einer Hilfswissenschaft, die der Erforschung der inneren Natur des Menschen dient, und die diese kenntnis vermitteln kan. Sie hat sich dabe: kritisch absugrenzen gegen ihr wesenfremde weltanschauliche Voraussetzungen, die mittaufen, und die das ihr eigene, aus der Heiligen Schrift erhobene Menscheverstandnis beeintrachtigen könnten. ${ }^{63}$ )

\section{DIE OBJEK VAN DIE PASTORAAT}

Pastoraat as verkondiging is gerig tot die mens in sy konkrete situasie „Veründigung vollzieht zich darum nicht im leeren Raum, sondern in einer konkreten Situation und ist bezogen auf Menschen, die sich in einer bestimmten Lage befinden." ${ }^{1}$ )

Betref hierdie verkondiging wat gerig is tot die mens in sy konkrete situasie, die mens in sy totaliteit of slegs ' $n$ gedeelte van die mens? By Faber en Van der Schoot betref dit nie die mens in sy totaliteit nie maar slegs die siel van die mens. „Teenoor hierdie beskouing is daar egter andere (soos Roscam Abbing en Faber) wat die siel van die mens as voorwerp van die sielsorg beskou terwyl die mens se liggaam as objek van die barmhartigheidsdiens beskou word." 2 ) Dat die siel van die mens deur hulle afgesonder word as voorwerp van die pastoraat, blyk uit die feit dat hulle met groot voorliefde van die pastoraat praat as sielsorg. Voorts uit die feit dat dit vir hulle in die pastoraat nie gaan om die verkondiging van die Woord aan die mens, d.w.s. die mens in sy totaliteit nie maar om die selfontdekking, die opnuut rehabilitasie van 'n verstoorde proses, wat hoofsaaklik beperk is tot die psigiese. Die feit van hulle groot afhanklikheid van die Psigologie en Psigoterapie beklemtoon ook hierdie aspek.

Kan daar so 'n skerp grens getrek word tussen die siel en die liggaam van die mens, die een alleen afgesonder word as voorwerp van die pastoraat? Thurneysen wys hierdie moontlikheid beslis af as hy stel: „Seelsorge ist sorge um die Seele des Menschen. Die menschliche seele aber, um die es in der Seelsorge geht, ist nicht nur das Seelische im Mensshen, sondern Seele ist nach der Heilige Schrift zu verstehen als die personale Gansheit des Menschen nach Leib, Seele und Geist unter dem Anspruch Gottes. ${ }^{1{ }^{3}}$ )

Volgens Thurneysen is sielsorg sorg vir die siel van die mens soos die woord aandui. Wat verstaan ons nou onder die begrip siel? Hier is dit nie van belang hoe verstaan ek as individu die begrip siel nie, maar wat sê die Bybel daarvan.

63) E. Thurneysen, a.w., bls. 174.

1) H. Girgensohn, Heilende Krüfte der Seelsorge, Gottingen, bls. 9.

2) J. I. de Wet, Diktaatlesings, a.w., bls. 1.

3) E. Thurneysen, a.w., bls. 45. 
Juis hier waar dit gaan oor die siel van die mens as voorwerp van die pastoraat, het al baie ontsporing plaasgevind. Juis op hierdie punt gebeur dit menigmaal, soos ook by Faber en Van der Schoot, dat die pastoraat verindividualiseer en verpsigoliseer word.

Dan geld alleen die mens se "Zielenleven, en dan in den typisch bergrensden modernen zin te verstaan, hun gemoedsleven, met de daarin voorkomende behoeften of conflicten en moeilykheden." ${ }^{\prime 4}$ )

Met die verindividualiseringsproses soos aangetref by Faber en Van der Schoot, word die gemeente gewoonlik opgelos. Die gemeente geld nie meer nie, maar net die enkeling wat dan sogenaamd op sy eie geloof salig word. Vir die pastor gaan dit in dié geval ook gewoonlik net om die siel wat gewen moet word. Die predikant wat hierdie idee toegedaan is, is ook nie veel bekommerd oor die preek wat hy Sondag moet hou nie. By hom gaan dit net om 'n meedoënlose rondjaery om sg., ,siele te wen", en om mense van psigologiese konflikte te bevry. Met hierdie misverstand word die pastoraat vir die enkeling so ' $n$ groot las dat hy dit self nie meer kan dra nie. Hierdie beskouing van die pastoraat vind ons veral by die Piëtiste en Metodiste vanweë hulle intense belangstelling vir die individuele bekeerde met sy sie persoonlike religieuse ervarings.

As uitgangspunt vir de befaling van die begrip "seele" in die Bybel kan ons Genesis 2:7 neenı. Die Afrikaanse vertaling lui: „En die Here God het die mens geformeer uit die stof van die aarde en in sy neus die asem van die lew1? geblaas. So het die mens dan ' $n$ lewende siel geword."

'n Fiesiese wese is geformeer uit die stof. Hierdie fisiese wese is egter nog nie mens, ,lewende siel", nie, nog nie mens in die volle sin van die woord nie. Vir hom, dis fisiese wese, om dit te wees, is nog ' $n$ besondere werk van God nodig. Hy het ,in sy neus die asem van die lewe geblaas." Nou eers het hy "n lewende menslike wese, 'n mens in die volle sin van die woord, " $n$,lewende siel", geword. Eers die "siel" het hom gemaak wat hy is $\mathrm{nl}$. ' $\mathrm{n}$ mens. Daarom leef die mens sy lewe as mens alleen in terme van die siel waardeur hy aktueel in eksistensie gekom liet. Maar hy leef dit ook as die een voltooide lewe wat hom gegee is in liggaam en siel. Sonder liggaam is die mens nie mens nie, en sonder siel ook nie. Beide liggaam en siel, onlosmaaklik van mekaar, vorm die mens. Die twee hoort byeen soos die hand en die vingers. Die een kan nie sonder die ander nie en tog is dit twee dele.

Hierdie eenheid en geskeidenheid van liggaam en siel is van baie groot belang. .Die Seele ist eine dem Leib gegenüber selbständige, soveräne Grosze; sie ist keine blosze Funktion des Leibes. Aber auch der Leib ist Wesensbestandteil des Menschen; er ist nichts Nebensächliches, nicht nur ein Anhängsel, ein blosze Behäuzung oder gar ein Gefängnis in welchem der Mensch seiner seele

1) G. Brillenburg Wurth, Verkondiging en Zielszorg, bls. 23. 
nach sich befindet."5) Uit dié stelling van Thursneysen kan ons konkludeer dat die mens die liggaam van sy siel is. Karl Barth keer dit om en sê die mens is die siel van sy liggaam. Dus die mens se mens-wees berus net soveel op sy siel as op sy liggaam. Beide liggaam en siel moet opgevat word as 'n eenheid, wat die totaliteit van die menswees uitdruk sowel as elke individuele aktiwiteit.

Nóg liggaam nóg siel is 'n grootheid op sigself. Dit kry eers betekenis deur die handeling van God, deur die inblaas van die asem in die mens se neus. Eers deur die handeling van God word die mens „waarlik mens."

As ons daarom praat van siel, dan bedoel ons die mens in sy totalite.t, beide liggaam en siel, want die een kan nie sonder die ander bestaan nie. As ons die dualisme liggaam en siel verabsoliteer soos die Griekse filosofie, bly slegs iets oor wat ons liggaam kan noem en naas dit iets .,seelisches". Dan is daar nie meer 'n menslike eksistensie, 'n menslike wese wat deur die ,inblaas van die asem van God" tot stand gekom het nie. Dan val die pastoraat ook uiteen soos by Faber en Van der Schoot. „Aan die eenkant word die siel gestel as die absolute, die goeie. Dit vind ons veral by die Roomse kerk waar alles wat liggaamlik is, verag word. Aan die anderkant kan 'n verkeerde opvatting oor hierdie geskeidenheid en eenheid van liggaam en siel weer lei tot 'n oorbeklemtoning van die eenheid van die liggaam en die siel. Dan is ons binne die "Social gospel”, dan is brood vir die liggaam ook voedsel vir die siel. Dan is Woordverkondiging nie meer die heiligste plig van die kerk nie maar die handhawing van menslike regte en die waardigheid van die mens. ${ }^{6}$ )

Uit Genesis 2 vers 7 kan ons drie konklusies trek wat van belang is vir die pastoraat: -

(i) Liggaam en siel staan nie los van mekaar nie. Dit vorm in eenheid en tegelyk ' $n$ dualisme. Hierdie feit is van baie groot belang vir die pastoraat soos ons hierbo aanyetoon het. Die pastor sal moet onthou dat dit in die pastoraat nie net om die siel van mens, nie net om innerlike psigologiese konflikte gaan nie, maar om die mens in sy totaliteit.

(ii) Alleen deur die handeling van God is die mens wat hy is. Sy hele bestaan het hy aan God te danke. Deur God en God alleen is die mens wat hy is. „Er lebt sein leben als ein von Gott geliehenes leben." 7 ) God is die Skepper en die mens is die skepsel. Hierdie "Geschaffensein" van die mens betref weer sy hele wese, beide liggaam en siel. Daar is dus niks goddeliks in die mens nie, nie 'n innerlike

5) E. Thurneysen, a.w., bls. 46.

6) J. I. de Wet, Pimeniek. Diktaatlesings 1965.

7) E. Thurneysen, a.w., bls. 17. 
kontakpunt wat kan dien as aanknopingspunt vir die evangelie nie. ${ }^{8}$ )

Vir die pastoraat is hierdie „Geschaffensein" van die mens deur God van groot belang. As die pastor dit voor oë hou, sal sy houding tot sy medemens en sy gemeente nooit die van minagting wees nie. Dit sal ook nie 'n oorskatting van die menslike lewe wees wat aan die idealistiese grens nie. Die pastor sal nie soos Faber en Van der Schoot dink dat die mens self na 'n psigoterapeutiese proses tot „selfontdekking" kan kom nie. Aan die eenkant sal onthou word dat die mens skepsel van God is, en nie God self nie. Aan die anderkant dat hierdie mens sy lewe van God ontvang het.

(iii) Die Woord betref die mens se totaliteit. Beide liggaam en siel. Siel en liggaam staan naas mekaar maar tog geskei. Die handeling van God staan bo altwee as 'n derde element wat beide siel en liggaam raak. Hierdie derde is God se Gees en Woord. Alleen die aanspraak van God is beslissend vir die mens. As hy onder hierdie aanspraak leef, het hy in de totaliteit van sy bestaan, in liggaam en siel, 'n „gcistliche" mons geword, 'n mens wat die roeping van „ware mens wees" vervul. Waar die pastorale gesprek soos by Faber en Van dor Schoot slegs gerig is tot die siel van die mens, kan die mens in sy totaliteit nooit staan onder die Woord nie.

Nadat gostel is clat die pastoraat gerig is tot die mens in sy totaliteit, moct nou ten slotte die vraag beantwoord word tot watter mense die pastoraat gerig is.

Reeds Claus Harms het die objek van die pastoraat beperk tot .,afgeweken, kranken, enz." ${ }^{\text {') }}$ Vir Faber en Van der Schoot is die objek van die pastoraat ook nie alle mense nie, maar slegs die wat een of ander "kranketoestand" beleef.

Die Skrif ken nie hierdie beperking nie. Die Skrif gee juis getuienis dat die hele gemeente die objek van die pastoraat is. ${ }^{10}$ ) Per slot van sake is dit nie net die sieke en behoeftige wat in nood verkeer nie, alle mense verkeer vanweë sy gebroke, sondige toestand midde in die dood. Nie alleen die besondere gevalle nie maar elke gemeentelid het die bevrydende Woord van God in Jesus Christus nodig.

Waar besondere gevalle van sielkundige afwykings of besondere nood voorkom, is wel besondere sorg nodig. Hierdie besondere gevalle moet wel besondere aandag in die pastoraat kry

8) Vir verdere ondersoek na die begrip liggaam en siel sien J. Steyn, Die Bybelse Beskouing van die mens as Eenheid en die Betekenis daarvan vir die Sielsorg. Hervormde Teo'ogiese Studies, Jaargang 23, Afl. 4, bls. 1.

9) P. Biesterveld, Het Huisbezoek, bls. 48.

10) Sien Matt. 28:19, Handelinge 20:28. 
maar mag nie afgesonder word as die enigste objek van die pastoraat nie. In die geval van sielkundige afwykings sal die pastor moet onthou dat hy nie sielkundige is nie maar dienaar van die Woord. Dit is nie sy taak om die sielkundige probleem op te los nie, maar om die betrokkene te verwys na hom wat daarvoor opgelei is. Na die sielkundige behandeling moet die betrokkene deur die pastor besoek word, want dit is per slot van sake eers deur die verkondigde Woord wat daar ware bevryding kom. Miskien lê hier die grondfout van Faber en Van der Schoot, nl. dat hulle die terrein tussen Pastoraat en Psigologie vermeng het.

Hierdie kritiese bespreking vin Faber en Van der Schoot se begrip pastoraat kan afgesluit word met die woorde van dr. J. Cremer: „In haar te waarderen is, dat zij weer veel meer ernst heeft gemaakt met de religie als religie, als gemeenskap met God te beschouwen. Doch ook hier moet dit bezwaar ingebracht worden, dat zij opgaat in die constatering van alle psigologisch-antropologische zijde der religie, terwijl de metaphysische haar ontgaat of door haar ontkend word; zij laat objektieve norm los, zij neem kritiekloos allerlei subjectieve elementen op, zij is daarin onbetroubaar en zij stell en de psychologie voor de religie wat uitloopt op een „eigenwillige" anthropologie." ${ }^{11}$ )

\section{Samevattende Kritiek}

1. Die Poimeniek word uitgelewer aan sy hulpwetenskappe $\mathrm{nl}$. Psigologie en Psigoterapie.

2. Pastoraat is hier nie primêr verkondiging nie, maar aanloop tot en resultaat van ' $n$ psigo-analitiese Proses.

3. Die primêre doel van die pastoraat is nie opbou van die gemeente nie, maar "selfontdekking", "self bevryding" van die enkeling.

4. Die vooraf ",counselling"-proses verdring die Woord wat verkondig word.

5. Die objek van die pastoraat is nie die hele mens en alle mense nie, maar hoofsaaklik die psigiese van die mens en slegs sommige afwykende gevalle.

i1) K. Dijk, De Dienst der Kerk, bls. 169. 